\title{
Gluten-Free Flat Bread and Biscuits Production by Cassava, Extruded Soy Protein and Pumpkin Powder
}

\author{
Mona M. A. Aly, Hinar A. Seleem* \\ Department of Crops Technology Research, Food Technology Research Institute, Agricultural Research Center, \\ Giza, Egypt \\ Email: hanhona853@hotmail.com
}

Received 4 May 2015; accepted 17 May 2015; published 20 May 2015

Copyright (C) 2015 by authors and Scientific Research Publishing Inc. This work is licensed under the Creative Commons Attribution International License (CC BY). http://creativecommons.org/licenses/by/4.0/

(c) (i) Open Access

\begin{abstract}
In recent years, there has been an increase in demand of gluten free products that are suitable for people with celiac disease. The present study was carried out to produce gluten free flat bread and biscuits with good quality. The ingredients under this study were cassava flour, rice flour, extruded soy protein (ESP) and pumpkin powder. Four levels of ESP were used for production of flat bread and biscuits: $2.5 \%, 5 \%, 7.5 \%$ and $10 \%$ for flat bread and $5 \%, 10 \%, 15 \%$ and $20 \%$ levels for biscuits. Results of flat bread samples showed that protein, fat, ash and fiber contents increased in all samples as increasing the level of ESP. Flat bread at level 10\% ESP had the highest value of $\beta$ carotene. Alkaline water retention capacity (AWRC) at zero time and $24 \mathrm{~h}$ of flat bread storage had high values for levels $2.5 \%$ and $5 \%$ ESP. Water holding capacity (WHC) increased insignificantly by increasing the level of ESP. Color measurements revealed that the lightness decreased and the redness increased with increasing the level of ESP. Sensory evaluation of flat bread revealed that $\mathbf{2 . 5 \%}$ followed by $5 \%$ ESP level had high score of overall acceptability. Physical properties of biscuits indicated that as the level of ESP increased the diameter, thickness, volume and specific volume decreased. Biscuits sample with $20 \%$ ESP had the highest values of protein, fat, ash and fiber but the lowest in total carbohydrates. Also $\beta$-carotene and vitamin A content increased in biscuit samples. Caloric values of biscuits in all treated samples were lower than control. Lightness decreased while redness increased with increasing the level of ESP. Data of texture profile analysis (TPA) showed that hardness and adhesiveness (g) increased as ESP level increased. Sensory evaluation of biscuits showed that addition of ESP at 20\% level decreased significantly texture score from 9.51 to $6.61(\mathrm{P}<0.05)$ but insignificantly affected the other sensory scores.
\end{abstract}

\section{Keywords}

Celiac Disease, Rice Flour, Cassava Flour, Extruded Soy Protein, Pumpkin Powder, $\beta$-Carotene,

\footnotetext{
${ }^{*}$ Corresponding author.
} 


\section{Color, Texture Profile Analysis, Flat Bread, Biscuits}

\section{Introduction}

Celiac disease (CD) is an autoimmune and chronic disorder in which the mucous membrane of the small intestine is damaged in gluten-intolerant individuals. CD is caused by not only a reaction to gliadin in wheat prolamin but also high molecular glutenin and subunits of gluten protein consequents in damage and inflammation to the small intestine and causes malnutrition [1]. One person out of two hundred has been diagnosed with this disease and some studies have stated that the dominant of this disease is 1 in 100 worldwide [2]. This chronic disease is recognized as long-life disease and the only solution is adherence stickiness to gluten-free products. But this is not easy as many foodstuffs contain gluten [3]. Middle Eastern countries and many of families in the world now consume the flat bread type. In general, flat bread is a simple formula produced by a few ingredients. It is consumed either by incorporating foods such as meat or vegetables in the dough or as final products in which food can be placed in the pocket of the two layer flat bread. A correct balance of viscoelastic properties is considered to be an important during flat bread making [4].

Rice is the main staple food for many countries, providing $20 \%$ of the food energy supply in the world. It is known as queen among cereals after wheat. Rice is characterized by low prolamin, hypoallergenic activity, insipid taste, low sodium and high digestible carbohydrate contents, which is suitable to be incorporated into celiac diets [5].

Rice flour, corn and cassava starches were used to obtain non-gluten bread. The type of starches (granule size, amylose/amylopectin content, chemical, and physical modification) could influence the batter consistency and the gelatinization-retrogradation rate; these parameters strongly related to bread quality [6].

Cassava flour can be used for many people suffering from celiac disease, a chronic enteropathy characterized by an inadequate immune response to ingested gluten from wheat, rye, barley, and triticale [7]. Reduction in the consumption or outright elimination of gluten-free foods would be desirable [8]. Cassava flour (CF) is one of the major products from cassava roots treated in the world food market [9]. Cassava flour has also continued to find wider applications in foods, feed and chemical industries [10].

In particular, proteins isolated from legumes and dairy sources are most often added to gluten-free products [11].

Hydrocolloids are substances that are used as additives for the purpose of reproducing similar viscoelastic properties to the gluten. They are water-soluble polysaccharides, with varied chemical structures that confer certain properties that make it of a suitable functional application [12]. Hydrocolloids such as pectin, guar gum and xanthan gum are added to naturally gluten-free flours to mimic the viscoelastic properties of gluten and to improve structure, sensory attributes and shelf-life of these products [11].

Pumpkins are extensively grown in tropical and subtropical countries. Traditionally it is consumed as freshly boiled, steamed or processed food items such as soup or curry. Pumpkin is high in $\beta$-carotene, which gives its yellow or orange color [13]. Consumption of foods containing carotene helps in prevention of eye disorders, cancer and skin diseases [14]. Incorporation of $\beta$-carotene rich foods in diets is the best measure to improve vitamin A nutrition of individuals to overcome the problems and diseases caused by vitamin A deficiency [15].

The development of good quality gluten free bread is a serious task. Therefore, many researchers have investigated the substitution of gluten by ingredients able to mimic its functional properties [16].

Bread is a staple diet that is consumed daily and its quality and sensory attributes are highly considered by consumers. But the quality of the gluten-free bread might be different than conventional heat bread due to lack of gluten [3].

Bread staling involves crumb firming and has been attributed to several factors including recrystallization of amylopectin, water redistribution, and the state of amorphous phase. In wheat bread, the gluten network slows down the movement of water from the bread crumb to crust, and thus the lack of this structure in gluten-free bread should enhance the water movement resulting in bread that is more prone to stale [17].

Gluten-free biscuits are typically round cakes of bread that are leavened with baking powder, baking soda or sometimes yeast. It may also refer to cookies or crackers. They are mostly sweet and in history they were used by travelers as they were long-lasting foods and easy to carry [18]. 
The diet of celiac patients must be completely free of any gluten, so all the products from wheat, rye, barley and oat must be replaced with corn, rice, millet equivalents and various types of starch (corn, rice and potato) or appropriate mixtures [11].

This investigation aimed to use cassava flour and extruded soy protein (ESP) in preparing gluten-free flat bread and biscuits with high nutritional value for people suffering from celiac disease.

\section{Materials and Methods}

\subsection{Materials}

Broken rice supplied by Rice Milling Company, Dakahlia, Egypt. Cassava Flour was obtained from Royal House Market, Heliopolis, Cairo, Egypt. Extruded soy protein (ESP) was obtained from AWA for food additives company Alex., Egypt. Pumpkin vegetable, salt, sugar powder, butter, eggs and baking powder are purchased from local markets, Cairo, Egypt. Xanthan was obtained from Doves farm foods Co. UK.

\section{Chemicals}

All chemicals used were purchased from Algomhorya Company, Giza, Egypt.

\subsection{Preparation of Raw Materials}

\subsubsection{Rice Flour}

The broken rice was directly ground into flour using the mixer grinder and sieving through 40 mesh sieve and placed on a cooling rack in refrigerator [19].

\subsubsection{Pumpkin Powder}

The peeled pumpkin was converted into $10 \mathrm{~mm}$ size cubes then cut into slices $(2 \mathrm{~mm})$ and subjected for pretreatments such as blanching $\left(94^{\circ} \mathrm{C}\right.$ for $\left.2 \mathrm{~min}\right)$ then dried for preparation of powder using vacuum dryer (Vacuum Oven ADP-31 Made In Japan). Vacuum drying of pumpkin slices was carried out at $80^{\circ} \mathrm{C}$ and $700 \mathrm{~mm} \mathrm{Hg}$ vacuum. The dried pumpkin was milling and sieving through an 40-mesh and placed on a cooling rack in refrigerator [20].

\subsubsection{Preparation of Products}

1) Flat bread

The flat bread blends shown in Table 1. Formulas were treated, hydrothermally (as a prelimimary study) to reach the quantity of warm water $(60,65,70,75$ and $80 \mathrm{ml})$. For preparation flat bread dough, warm water

Table 1. Formulation and added ingredients for flat bread and biscuits.

\begin{tabular}{|c|c|c|c|c|c|c|c|c|c|c|}
\hline \multirow{2}{*}{ Ingredients (g) } & \multicolumn{5}{|c|}{ Flat bred } & \multicolumn{5}{|c|}{ Biscuits } \\
\hline & 1 & 2 & 3 & 4 & 5 & 1 & 2 & 3 & 4 & 5 \\
\hline Rice flour & 50 & 50 & 50 & 50 & 50 & 50 & 50 & 50 & 50 & 50 \\
\hline Cassava flour & 50 & 50 & 50 & 50 & 50 & 50 & 50 & 50 & 50 & 50 \\
\hline $\mathrm{ESP}^{*}$ & 0.0 & 2.5 & 5.0 & 7.5 & 10 & 0.0 & 5 & 10 & 15 & 20 \\
\hline Pumpkin powder & 0.0 & 7 & 7 & 7 & 7 & 0.0 & 7 & 7 & 7 & 7 \\
\hline Xanthan & 0.1 & 0.1 & 0.1 & 0.1 & 0.1 & 0.1 & 0.1 & 0.1 & 0.1 & 0.1 \\
\hline Salt & 1 & 1 & 1 & 1 & 1 & - & - & - & - & - \\
\hline Sugar & - & - & - & - & - & 85 & 85 & 85 & 85 & 85 \\
\hline Whole egg & - & - & - & - & - & 52 & 52 & 52 & 52 & 52 \\
\hline Baking powder & - & - & - & - & - & 5 & 5 & 5 & 5 & 5 \\
\hline Butter & 2 & 2 & 2 & 2 & 2 & 80 & 80 & 80 & 80 & 80 \\
\hline Warm water (ml) & 60 & 65 & 70 & 75 & 80 & - & - & - & - & - \\
\hline
\end{tabular}

*ESP: Extruded soy protein. 
added to formulated flour and gelatinized for 3 min on Steam cooker. The dough of each formula divided into $15 \mathrm{~g}$ pieces. Then, every piece of dough shaped, into roller shape (2 mm thick and $15 \mathrm{~mm}$ diameter) and baked in electric oven at $250^{\circ} \mathrm{C}$ for $3 \mathrm{~min}$. Then air cooled, packed in polyethylene bags.

2) Biscuits

The biscuit blends shown in Table 1. It prepared according to the methods described by Oyewole et al. [21]. Butter and sugar were mixed in (a Kenwood mixer) at a medium speed until a light and fluffy cream was formed, added egg and continue the mixing. Cassava flour, rice flour, (ESP), pumpkin powder and xanthan were slowly added to the mixture then rolled on a flat rolling board. Circular biscuits were cut, placed on greased baking trays and baked in an electric oven (Kumatel, Turkey) at $160^{\circ} \mathrm{C}$ for $15 \mathrm{~min}$.

\subsection{Analysis}

\subsubsection{Chemical Composition}

Proximate analysis including moisture, protein, fat, ash and crude fiber were carried out according to the methods of AOAC [22]. Carbohydrates content was calculated by difference.

\subsection{2. $\beta$-Carotene Content}

$\beta$-carotene was determined by using water-saturated $n$-butanol (WSB) according to the method outlined by Santra et al. [23] A calibration curve was made from known quantities of $\beta$-carotene. $\beta$-carotene content was expressed as $\mu \mathrm{g} / 100$ on dry weight basis. Vitamin A value calculation was performed based on vitamin A activity of the $\beta$-carotenes according to the conversion factor provided by the Food and Nutrition Board, Institute Of Medicine [24]. Vitamin A value was expressed in retinol activity equivalents (RAE), which represents vitamin A activity as retinol. Where, $12 \mu \mathrm{g}$ of $\beta$-carotene from foods are required to provide the body with $1 \mu \mathrm{g}$ of retinol, giving dietary $\beta$-carotene an RAE ratio of 12:1.

\subsubsection{Alkaline Water Retention Capacity of Flat Bread during Storage}

Alkaline water retention capacity (AWRC) values of flat bread were measured at $0,24,48$ and $72 \mathrm{~h}$ of bread storage at $-20^{\circ} \mathrm{C}$ according to Yamazaki [25] and modified by Kitterman and Rubenthaler [26].

\subsubsection{Water Holding Capacity (WHC) of Flat Bread}

Water holding capacity (WHC) was performed according to the method of Beuchat [27].

\subsubsection{Total Calories of Flat Bread and Biscuits}

Total calories of flat bread and biscuits were calculated from the following equation as reported by James [28]. Energy value $=4$ (g protein $+\mathrm{g}$ carbohydrates $)+9$ (g fat).

\subsubsection{Physical Properties of Biscuits}

The diameter and thickness of biscuits were measured with a venire caliper. Spread ratio was calculated from the ratio of diameter to thickness as described by Gains [29] method. The average of weight biscuit (5 piece) was measured in (g). Volume $\left(\mathrm{cm}^{3}\right)$ was measured by displacement of rapeseeds and specific volume was determined by dividing volume $\left(\mathrm{cm}^{3}\right) /$ weight $(\mathrm{g})$. Density was calculated by dividing weight $(\mathrm{g})$ out volume $\left(\mathrm{cm}^{3}\right)$ and expressed as $\left(\mathrm{g} / \mathrm{cm}^{3}\right)$ [30]. The specific volume of biscuits was determined according to the method described in AACC [31].

\subsubsection{Color Measurements of Flat Bread and Biscuits}

External color of the products was measured according to the method outlined by McGurie [32] using a handheld Chromameter (model CR-400, Konica Minolta, Japan).

\subsubsection{Texture Profile Analysis (TPA) of Biscuits}

Hardness and adhesiveness of biscuits were measured by using Brookfield Engineering Lab. Inc., Middleboro, MA 02346-1031 USA [31].

\subsubsection{Organoleptic Evaluation of Products}

1) Flat bread 
Flat bread samples were organoleptically evaluated for its sensory characteristics. Half slice of each bread sample was served for ten panelists on white, odor and disposable plates. Samples were scored for, taste, chewing ability, texture, aroma, color and overall acceptability using a score from 1 to 10 . The evaluation was carried out according to the method of Land and Shepherd [33].

2) Biscuits

Biscuit samples were organoleptically evaluated by ten panelists for its sensory characteristics: appearance, color, odor, texture, taste and overall acceptability as the method described by Larmond [34]. The maximum score of each attribute was (10) degrees.

\subsection{Statistical Analysis}

The obtained data from chemical, physical and sensory evaluation were exposed to analysis of variance (ANOVA). Duncan's multiple range tests at $(\mathrm{P} \leq 0.05)$ level was used to compare between means.

\section{Results and Discussion}

\subsection{Chemical Composition of Raw Materials}

The proximate composition of raw materials used for the preparation of bakery products (flat bread and biscuits) is shown in Table 2. The obtained data revealed that the highest content of protein found in extruded soy protein (ESP) 56.82\%. While, the lowest value was found in cassava flour (1.05\%). Fat content ranged from 0.62 up to $4.00 \%$ for cassava flour and (ESP), respectively. The values were obtained agreed with those reported by Tharise et al. [35] and Ogunjobi and Ognwolu [9]. Pumpkin powder had the highest content of ash 5.83\% followed by ESP (4.78\%). These results agreed with Pongjanta et al. [36]. Fiber content was (1.94\%, 1.09\%, 2.47\% and 2.98\%) for rice flour, cassava flour, (ESP) and pumpkin powder, respectively. Cassava flour, rice flour and pumpkin powder had high carbohydrates content 95.83, 89.38 and 84.30\%, respectively. Whiles, ESP had the lowest value $31.92 \%$. These results are in agreement with Tharise et al. [35].

\subsection{Flat Bread}

\subsubsection{Chemical Analysis of Flat Bread}

The chemical composition of flat bread are given in Table 3. Data showed that protein content increased as increase ESP level. The highest value was 9.15\% for sample No. 5 (10\% ESP). On the other hand, fat, ash and fiber contents were increased significantly in all samples. This may be due to the addition of ESP. These results agreed with Hegazy et al. [37] who showed that the chemical composition of gluten free bread samples evident increase in protein, fat and ash contents in all gluten free bread samples, probably due to addition of soy flours. Carbohydrate content decreased significantly in all same samples compared with control (sample No. 1). This may be attributed to the increment in protein content.

Carotenoids have been extensively studied due to their important biological functions for humans and also as natural pigments. Relations between carotenoid and vitamin A were found, and some of them have provitamin A activity ( $\alpha$-carotene, $\beta$-carotene, $\gamma$-carotene, $\beta$-zeacarotene and others), which could be transformed in vitamin A inside the animal organism [38].

Data in Table 3 represents $\beta$-carotene $\mu \mathrm{g} / 100 \mathrm{~g}$ flat bread. It could be noticed that $\beta$-carotene content ranged

Table 2. Chemical composition of raw materials (g/100g) on dry weight basis.

\begin{tabular}{|c|c|c|c|c|}
\hline Parameters (\%) & Rice flour & Cassava flour & E.S.P ${ }^{*}$ & Pumpkin powder \\
\hline Protein & $7.09^{b}$ & $1.05^{\mathrm{d}}$ & $56.82^{\mathrm{a}}$ & $4.09^{c}$ \\
\hline Fat & $0.67^{\mathrm{c}}$ & $0.62^{c}$ & $4.00^{\mathrm{a}}$ & $1.39^{\mathrm{b}}$ \\
\hline Ash & $0.93^{\mathrm{c}}$ & $1.73^{\mathrm{c}}$ & $4.78^{b}$ & $5.83^{\mathrm{a}}$ \\
\hline Fiber & $1.94^{\mathrm{c}}$ & $1.09^{\mathrm{d}}$ & $2.47^{\mathrm{b}}$ & $2.98^{\mathrm{a}}$ \\
\hline Total carbohydrates & $89.38^{\mathrm{b}}$ & $95.83^{\mathrm{a}}$ & $31.92^{\mathrm{d}}$ & $84.30^{c}$ \\
\hline
\end{tabular}

*Extruded soy protein. Data are presented as means $(\mathrm{n}=3) \&$ means within a row with different letters are significantly different at $(\mathrm{P} \leq 0.05)$. 
Table 3. Phsico-chemical analysis of flat bread on dry weight basis.

\begin{tabular}{|c|c|c|c|c|c|}
\hline \multirow{2}{*}{ Parameters (\%) } & \multicolumn{5}{|c|}{ Flat bread samples } \\
\hline & 1 & 2 & 3 & 4 & 5 \\
\hline Protein & $4.68^{\mathrm{e}}$ & $5.76^{\mathrm{d}}$ & $6.84^{\mathrm{c}}$ & $7.93^{\mathrm{b}}$ & $9.15^{\mathrm{a}}$ \\
\hline Fat & $2.68^{\mathrm{e}}$ & $2.75^{\mathrm{d}}$ & $2.83^{\mathrm{c}}$ & $2.92^{\mathrm{b}}$ & $3.15^{\mathrm{a}}$ \\
\hline Ash & $1.33^{\mathrm{e}}$ & $1.46^{\mathrm{d}}$ & $1.59^{\mathrm{c}}$ & $1.72^{\mathrm{b}}$ & $1.85^{\mathrm{a}}$ \\
\hline Fiber & $0.57^{\mathrm{e}}$ & $0.78^{\mathrm{d}}$ & $0.91^{\mathrm{c}}$ & $1.05^{\mathrm{b}}$ & $1.18^{\mathrm{a}}$ \\
\hline Total carbohydrates & $90.74^{\mathrm{a}}$ & $89.25^{\mathrm{b}}$ & $87.83^{\mathrm{c}}$ & $86.38^{\mathrm{d}}$ & $84.67^{\mathrm{e}}$ \\
\hline \multicolumn{6}{|l|}{ Carotenoids } \\
\hline$\beta$-carotene $(\mu \mathrm{g} / 100 \mathrm{~g})$ & $102.10^{\mathrm{b}}$ & $465.30^{\mathrm{a}}$ & $467.90^{\mathrm{a}}$ & $481.30^{\mathrm{a}}$ & $484.40^{\mathrm{a}}$ \\
\hline Vitamin A ( $\mu$ g RAE) ${ }^{* *}$ & 8.51 & 38.80 & 39.00 & 40.10 & 40.40 \\
\hline Caloric value (kcal/100g) & 406.90 & 404.80 & 404.20 & 403.50 & 403.60 \\
\hline$\left(\mathrm{WHC}^{*}\right)$ & $3.61^{\mathrm{b}}$ & $3.74^{\mathrm{b}}$ & $3.77^{\mathrm{b}}$ & $3.82^{\mathrm{b}}$ & $4.07^{\mathrm{a}}$ \\
\hline
\end{tabular}

"WHC: Water Holding Capacity. ${ }^{* *}$ Retinol Activity Equivalent (RAE). 1 RAE $=1 \mu \mathrm{g}$ retinol, $12 \mu \mathrm{g} \beta$-carotene, whereas the RAE for preformed vita$\min \mathrm{A}$ is the same as Retinol Equivalent (RE). $1=(0 \mathrm{ESP}), 2=(2.5 \% \mathrm{ESP}), 3=(5 \% \mathrm{ESP}), 4=(7.5 \% \mathrm{ESP}), 5=(10 \% \mathrm{ESP})$. Data are presented as means $(\mathrm{n}=3)$ \& means within a row with different letters are significantly different at $(\mathrm{P} \leq 0.05)$.

from 102.10 to $484.40 \mu \mathrm{g} / 100 \mathrm{~g}$, where flat bread sample No. 5 exhibited the highest amount of $\beta$-carotene, while flat bread sample No. 1 (control) had the lowest value. This may be due to the addition of pumpkin powder during formulation Table 1. These results agreed with See et al. [39].

Vitamin A (retinol) is an essential nutrient needed in small amounts by human for the normal functioning of the visual system, growth, development and maintenance of epithelial cellular integrity, immune function and reproduction [40].

From the same Table 3 represents vitamin A values ( $\mu$ g RAE) expressed as $\beta$-carotene. As vitamin A calculations dependent on $\beta$-carotene content, therefore, their values followed a similar trend than that of $\beta$-carotene. Data in the same table indicated that flat bread sample No. 5 had the highest value of vitamin A $40.40 \mu \mathrm{g}$ RAE, while sample No. 1 had the lowest value $8.51 \mu$ g RAE. Provitamin A carotenoids are found in yellow vegetables [41].

The results in Table 3 showed that the caloric value of flat bread nearly the same in all samples, ranged from 403.50 to 406.90 calories/100g. These results are in agreement with Hanee and Yaseen [42].

The staling of large scale manufactured flat bread may become a critical factor consideration. Bread staling is a very complex process that cannot be explained by a single effect, amylopectin retrogradation, reorganization of polymers within the amorphous region, loss of moisture content, distribution of water content between the amorphous and crystalline zone, and the crumb macroscopic structure must participate in the staling process [43] [44]. Brennan et al. [45] and Guarda et al. [46] reported that xanthan stabilized starch gels and reduced starch retrogradation. Xanthan which lead pronounced effect on viscoelastic properties yielding strengthened and gave a farinograph and extensograph curves similar to the curve of wheat flour dough.

Hence, alkaline water retention capacity (AWRC) during storage of the flat bread is the important experiment for indication on staling degree and freshness. It was determined at different periods at $0,24,48$ and $72 \mathrm{~h}$ as shown in Figure 1 it could be noticed that AWRC values of flat bread samples of 1, 2, 3, 4 and 5 at zero time were (131.6, 155.1, 164.1, 173.6 and 179.9\%), respectively. After $24 \mathrm{~h}$ of storage sample (No. 2) had the higher (AWRC) compared with the other samples. Same trend was observed for this sample (No. 2) at 48 and $72 \mathrm{~h}$. This means that the $(2.5 \%)$ of ESP is suitable for production of gluten-free flat bread. These results are in agreement with Duska et al. [47] who mentioned that addition of ESP can be successfully used in a high quality gluten-free bread production. These results agreed with Sciarini et al. [7] reported that soy flours showed the best quality attributes: high specific volume, good crumb, appearance, soft texture and low staling rate. The addition of soy caused crumb softening and retarded bread staling as soy proteins had a high water holding capacity and they could interfere in starch retrogradation. 


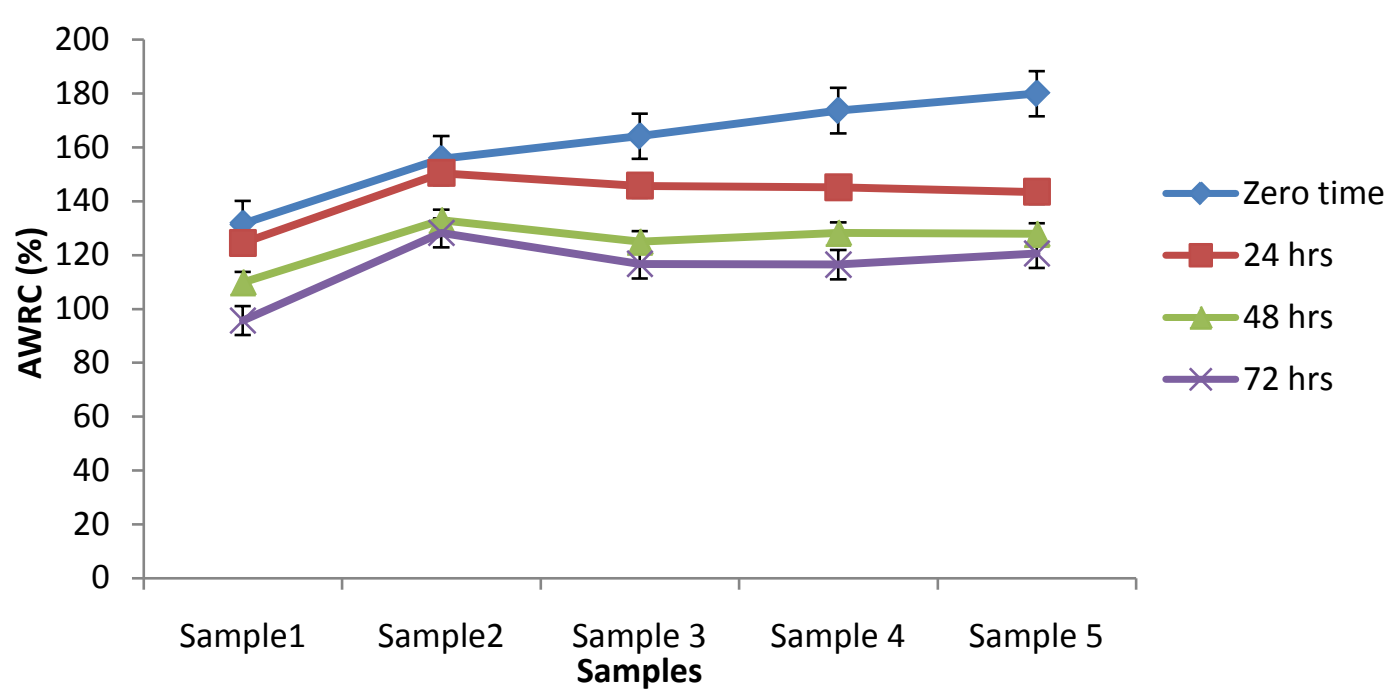

Figure 1. Alkaline water retention capacity of flat bread.

With respect to water holding capacity (WHC) it could be observed from the same Table 3 that WHC increased insignificantly by increasing the level of ESP except for sample No. 5 which supplemented with $10 \%$ ESP. Whereas, the increasing rate in water holding capacity was $12.74 \%$. Higher water absorption capacity of dough represents consistency which is desirable in bread making. Therefore, it is found that increase in ESP level slightly increase water holding capacity of the flat bread. These results are in agreement with Shaikh et al. [48] who reported that the water absorption is due to increase the quality of flour mixture which also increase the retention of moisture during dough processing for baked products.

\subsubsection{Color Measurements of Flat Bread}

Color is one of the most important quality attributes of flat bread [49] color measurements of the flat bread are illustrated in Table 4. Data indicated that supplementation with ESP and pumpkin powder significantly decreased the lightness (L) values. Control flat bread (No. 1) recorded the highest value, while flat bread No. 5 (10\%) ESP had the lowest value. The redness (a) and yellowness values of the flat bread significantly increased in all flat bread samples compared with control (No. 1). Like yellowness value, color saturation value (c) of flat bread No. 5 was found to be the highest value (31.03). Besides, supplementation with ESP and pumpkin powder decreased the hue angle significantly for all samples compared with control (86.15). The results in the same table showed that the color of flat bread samples No. 1, No. 2 and No. 3 was yellow while, samples No. 4 and No. 5 was orange yellow. These results are in agreement with those reported by Lorena et al. [50].

\subsubsection{Sensory Evaluation of Flat Bread}

Photographs of flat bread are illustrated in Figure 2. Sensory evaluation scores for the flat bread supplemented with different levels of ESP are presented in Table 5. Sensory evaluation was conducted according to ranking tests which was developed for assessing the food products acceptability, in which higher the score indicates to higher acceptability and quality [42].

The results revealed that flat bread No. 2 recorded the highest score of taste (9.36) followed by sample No. 3 (9.35), whereas the lowest score found in sample No. 1 (control). Chewing ability of flat bread No. 3 recorded the highest score (9.28), followed by No. 2 (8.92). This indicates that ESP addition at 2.5 and $5 \%$ level affected the chewing ability characteristics.

From the observed data in the same Table 5 texture score increased insignificantly in all samples compared with control. So, the addition of ESP improved the texture score. In respect the Aroma, there are no significant differences between all samples and control. Color score increased significantly for sample No. 2, No. 3 and No. 4 relative to control except for sample No. 5. Statistical analysis of sensory scores indicated that the best overall acceptability of the produced gluten-free flat bread can be obtained by 2.5 and/or 5\% ESP (samples No. 2 and No. 3) in bread formulation. These results are agreement with Lorena et al. [50] and Kadam et al. [51]. 


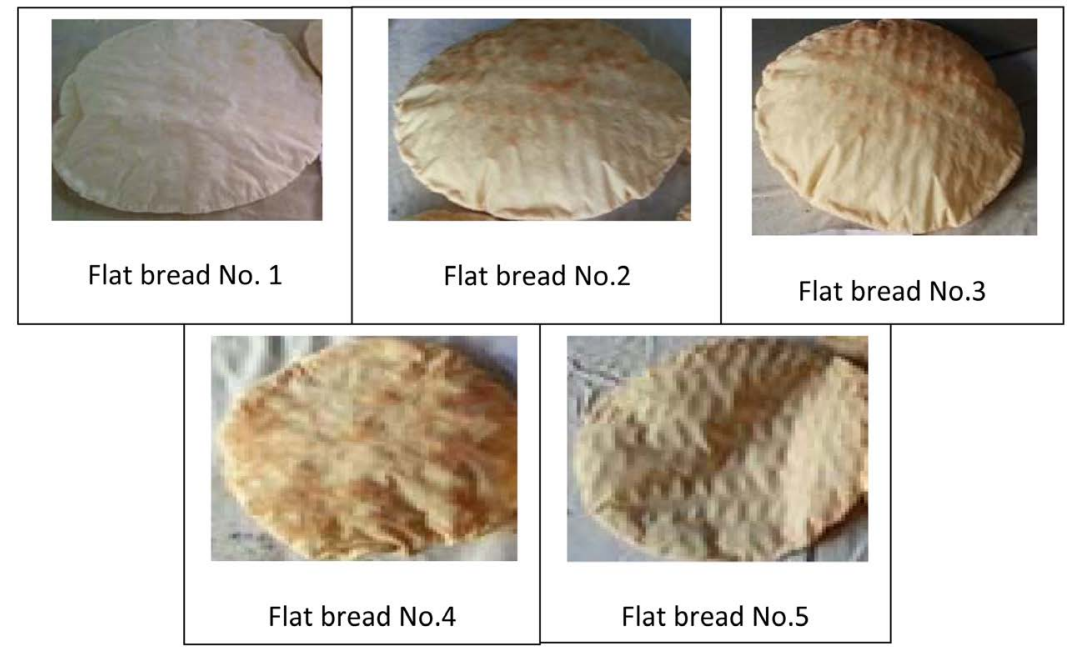

Figure 2. Flat bread photographs [1 = (0 ESP), 2 = (2.5\% ESP), $3=(5 \%$ ESP $), 4=$ (7.5\% ESP), 5 = (10\% ESP $)$.

Table 4. Color measurements of flat bread*.

\begin{tabular}{|c|c|c|c|c|c|}
\hline \multirow{2}{*}{ Parameters } & \multicolumn{5}{|c|}{ Flat bread samples } \\
\hline & 1 & 2 & 3 & 4 & 5 \\
\hline $\mathrm{L}$ & $67.61^{\mathrm{a}}$ & $64.87^{\mathrm{b}}$ & $59.64^{c}$ & $54.74^{d}$ & $49.76^{\mathrm{e}}$ \\
\hline $\mathrm{a}$ & $1.77^{\mathrm{e}}$ & $3.75^{d}$ & $4.76^{c}$ & $6.43^{\mathrm{b}}$ & $7.55^{\mathrm{a}}$ \\
\hline $\mathrm{b}$ & $26.32^{\mathrm{e}}$ & $27.45^{\mathrm{d}}$ & $27.93^{\mathrm{c}}$ & $28.35^{b}$ & $30.14^{\mathrm{a}}$ \\
\hline C & $26.46^{\mathrm{e}}$ & $27.67^{d}$ & $28.36^{c}$ & $29.04^{b}$ & $31.03^{\mathrm{a}}$ \\
\hline $\mathrm{h}$ & $86.15^{\mathrm{a}}$ & $82.14^{\mathrm{b}}$ & $80.25^{c}$ & $77.25^{\mathrm{d}}$ & $75.94^{\mathrm{e}}$ \\
\hline Color & Yellow & Yellow & Yellow & Orange yellow & Orange yellow \\
\hline
\end{tabular}

${ }^{*} \mathrm{~L}$ (lightness with $\mathrm{L}=100$ for lightness, and $\mathrm{L}=$ zero for darkness), a [(chromaticity on a green $(-)$ to red $\left.(+)\right]$, b $[($ chromaticity on a blue $(-)$ to yellow $(+)$ ], c (color saturation), h $\left[\right.$ (hue angle where $0^{\circ}=$ red to purple, $90^{\circ}=$ yellow, $180^{\circ}=$ bluish to green and $270^{\circ}=$ blue scale. Values are mean of three replicates $\pm \mathrm{SD}$, number in the same column followed by the same letter are not significantly different at 0.05 level. $1=(0 \mathrm{ESP}), 2=(2.5 \% \mathrm{ESP})$, $3=(5 \%$ ESP $), 4=(7.5 \%$ ESP $), 5=(10 \%$ ESP $)$. Data are presented as means $(n=3)$ \& Means within a row with different letters are significantly different at $(\mathrm{P} \leq 0.05)$.

Table 5. Sensory evaluation of flat bread.

\begin{tabular}{|c|c|c|c|c|c|}
\hline \multirow{2}{*}{ Parameters } & \multicolumn{5}{|c|}{ Flat bread samples } \\
\hline & 1 & 2 & 3 & 4 & 5 \\
\hline Taste (10) & $7.28^{\mathrm{b}}$ & $9.36^{\mathrm{a}}$ & $9.35^{\mathrm{a}}$ & $8.73^{\mathrm{a}}$ & $8.71^{\mathrm{a}}$ \\
\hline Chewing ability (10) & $7.13^{\mathrm{c}}$ & $8.92^{\mathrm{ab}}$ & $9.28^{\mathrm{a}}$ & $8.42^{\mathrm{abc}}$ & $7.57^{\mathrm{bc}}$ \\
\hline Texture (10) & $8.15^{b}$ & $9.27^{\mathrm{a}}$ & $9.58^{\mathrm{a}}$ & $9.50^{\mathrm{a}}$ & $9.42^{\mathrm{a}}$ \\
\hline Aroma (10) & $8.85^{\mathrm{a}}$ & $9.28^{\mathrm{a}}$ & $9.26^{\mathrm{a}}$ & $9.14^{\mathrm{a}}$ & $9.12^{\mathrm{a}}$ \\
\hline Color (10) & $7.28^{\mathrm{b}}$ & $8.92^{\mathrm{a}}$ & $9.00^{\mathrm{a}}$ & $9.14^{\mathrm{a}}$ & $8.43^{\mathrm{ab}}$ \\
\hline Overall Acceptability (50) & 38.69 & 45.75 & 46.47 & 44.93 & 43.25 \\
\hline
\end{tabular}

$1=(0$ ESP $), 2=(2.5 \%$ ESP $), 3=(5 \%$ ESP $), 4=(7.5 \%$ ESP $), 5=(10 \%$ ESP $)$. Data are presented as means $(n=10) \&$ Means within a row with different letters are significantly different at $(\mathrm{P} \leq 0.05)$. 


\subsection{Biscuits}

\subsubsection{Physical Properties of Biscuits}

Physical properties of biscuits such as diameter, thickness, spread ratio, weight, volume, specific volume and density were studied and given in Table 6. It was observed that as the level of ESP increased, the diameter, thickness, volume and specific volume of biscuits were decreased, whereas the spread ratio, weight and density of biscuits increased. The diameter, Thickness, volume and specific volume were decreased to 4.09, 0.93, 86.64 and 1.65 for sample No. 5 (20\% ESP), respectively. These results are in agreement with Kumar et al. [52]. While spread ratio, weight, and density increased to $5.29,49.80$, and 0.63 , respectively for the same sample. These results agreed with Ogunjobi and Ogunwolu [9] who found that the diameter of biscuits made from cassava and soy flour was $(5.51 \mathrm{~cm})$, while Onweluzo and Lwezu [53] showed that the spread ratio of biscuits supplemented with soy flour increased.

\subsubsection{Chemical Analysis of Biscuits}

The results in Table 7 showed the chemical composition of biscuits. There were significant differences in all parameters considered $(\mathrm{P}<0.05)$. The highest value for crude protein content was found in sample No. $5(15.37 \%)$

Table 6. Physical properties of biscuit.

\begin{tabular}{|c|c|c|c|c|c|}
\hline \multirow{2}{*}{ Parameters } & \multicolumn{5}{|c|}{ Biscuit samples } \\
\hline & 1 & 2 & 3 & 4 & 5 \\
\hline Diameter (cm) & $5.11^{\mathrm{a}}$ & $5.07^{\mathrm{ab}}$ & $5.02^{\mathrm{ab}}$ & $5.01^{\mathrm{b}}$ & $4.09^{\mathrm{c}}$ \\
\hline Thickness (cm) & $1.04^{\mathrm{a}}$ & $1.03^{\mathrm{ab}}$ & $1.02^{\mathrm{ab}}$ & $0.97^{\mathrm{bc}}$ & $0.93^{\mathrm{c}}$ \\
\hline Spread ratio & $4.44^{\mathrm{c}}$ & $4.84^{\mathrm{b}}$ & $4.92^{\mathrm{ab}}$ & $4.97^{\mathrm{ab}}$ & $5.29^{\mathrm{a}}$ \\
\hline Weight (g) & $42.20^{\mathrm{b}}$ & $43.40^{\mathrm{b}}$ & $48.10^{\mathrm{a}}$ & $49.10^{\mathrm{a}}$ & $49.80^{\circ}$ \\
\hline Volume $\left(\mathrm{cm}^{3}\right)$ & $108.10^{\mathrm{a}}$ & $105.70^{\mathrm{a}}$ & $100.30^{\mathrm{b}}$ & $97.67^{\mathrm{b}}$ & $86.64^{\circ}$ \\
\hline Specific volume $\left(\mathrm{cm}^{3} / \mathrm{g}\right)$ & $2.51^{\mathrm{a}}$ & $2.47^{\mathrm{a}}$ & $2.21^{\mathrm{ab}}$ & $1.91^{\mathrm{bc}}$ & $1.65^{\mathrm{c}}$ \\
\hline $\operatorname{Density}\left(\mathrm{g} / \mathrm{cm}^{3}\right)$ & $0.41^{\mathrm{b}}$ & $0.48^{\mathrm{b}}$ & $0.50^{\mathrm{b}}$ & $0.50^{\mathrm{b}}$ & $0.63^{\mathrm{a}}$ \\
\hline
\end{tabular}

$1=(0$ ESP $), 2=(5 \%$ ESP $), 3=(10 \%$ ESP $), 4=(15 \%$ ESP $), 5=(20 \%$ ESP $)$. Data are presented as means $(n=3) \&$ means within a row with different letters are significantly different at $(\mathrm{P} \leq 0.05)$.

Table 7. Chemical analysis of biscuits on dry weight basis.

\begin{tabular}{|c|c|c|c|c|c|}
\hline \multirow{2}{*}{ Parameters } & \multicolumn{5}{|c|}{ Biscuit samples } \\
\hline & 1 & 2 & 3 & 4 & 5 \\
\hline \multicolumn{6}{|l|}{ Chemical composition (\%) } \\
\hline Protein & $4.01^{\mathrm{e}}$ & $6.85^{\mathrm{d}}$ & $9.69^{c}$ & $12.53^{\mathrm{b}}$ & $15.37^{\mathrm{a}}$ \\
\hline Fat & $27.74^{\mathrm{e}}$ & $27.94^{\mathrm{d}}$ & $28.14^{\mathrm{c}}$ & $28.34^{\mathrm{b}}$ & $28.54^{\mathrm{a}}$ \\
\hline Ash & $0.58^{\mathrm{e}}$ & $0.82^{\mathrm{d}}$ & $1.06^{\mathrm{c}}$ & $1.30^{\mathrm{b}}$ & $1.54^{\mathrm{a}}$ \\
\hline Fiber & $0.55^{\mathrm{e}}$ & $0.67^{\mathrm{d}}$ & $0.80^{\mathrm{c}}$ & $0.92^{\mathrm{b}}$ & $1.04^{\mathrm{a}}$ \\
\hline Total carbohydrates & $67.12^{\mathrm{a}}$ & $63.72^{\mathrm{b}}$ & $60.31^{\mathrm{c}}$ & $56.91^{\mathrm{d}}$ & $53.51^{\mathrm{e}}$ \\
\hline \multicolumn{6}{|l|}{ Carotenoids } \\
\hline$\beta$-carotene $(\mu \mathrm{g} / 100 \mathrm{~g})$ & $865.20^{c}$ & $1158.30^{\mathrm{b}}$ & $1186.50^{\mathrm{b}}$ & $1247.30^{\mathrm{b}}$ & $1386.20^{\mathrm{a}}$ \\
\hline Vitamin A ( $\mu$ g RAE) ${ }^{*}$ & 72.10 & 96.50 & 98.80 & 103.90 & 115.50 \\
\hline Caloric value (kcal/100g) & 748.20 & 533.40 & 533.50 & 532.80 & 532.40 \\
\hline
\end{tabular}

$1=(0$ ESP), 2 = (5\% ESP), 3 = (10\% ESP), 4 = (15\% ESP), $5=(20 \%$ ESP). * Retinol Activity Equivalent (RAE). 1 RAE = $1 \mu \mathrm{g}$ retinol, $12 \mu \mathrm{g}$ $\beta$-carotene, whereas the RAE for preformed vitamin A is the same as Retinol Equivalent (RE). Data are presented as means ( $\mathrm{n}=3$ ) $\&$ Means within a row with different letters are significantly different at $(\mathrm{P} \leq 0.05)$. 
while, the lowest content found in sample No. 1 (4.01\%). Also the same sample No. 5 characterized by high fat, ash and fiber except for total carbohydrates which was the lowest (28.54\%, 1.54\%, 1.04\% and 53.51\%), respectively. This may be due to the high addition level of ESP (20\%).

These results are in agreement with Kumar et al. [52] who reported that defatted soy flour incorporation increased the nutritional status of biscuits due to high protein content. Soybean is an excellent health food and it contains $40 \%$ good quality protein, $23 \%$ carbohydrates and sufficient amounts of minerals and vitamins. Hence, it is superior to other plant proteins as it contains most of the essential amino acids except methionine, which is abundant in cereals, and it is most economical source of dietary protein. Kulkarni and Joshi [20] showed that the biscuit prepared with optimum level of replacement $2.5 \%(\mathrm{w} / \mathrm{w})$ from the pumpkin powder was found to be high in carbohydrate, crude fiber, carotene and mineral matter.

The results in Table 7 represents $\beta$-carotene $\mu \mathrm{g} / 100 \mathrm{~g}$ in biscuits. It could be noticed that $\beta$-carotene content ranged from 865.20 to $1386.20 \mu \mathrm{g} / 100 \mathrm{~g}$. Biscuit samples contained higher $\beta$-carotene contents than control sample (No. 1). The highest value was $1386.20 \mu \mathrm{g} / 100 \mathrm{~g}$ for sample No. 5 . These results agreed with Kulkarni and Joshi [20].

Data in the same table indicated that vitamin A ( $\mu$ g RAE) of biscuits expressed as $\beta$-carotene. As vitamin A calculations dependent on $\beta$-carotene content, therefore, their values followed a similar trend than that of $\beta$ carotene. It could be observed that sample No. 5 had the highest value of vitamin A $115.50 \mu \mathrm{g}$ RAE, while sample No. 1 (control) had the lowest value $72.10 \mu \mathrm{g}$ RAE. These results are in agreement with Booth et al. [54].

It could be noticed from Table 7 that the caloric values of produced biscuits in all samples were lower than control (No. 1). This may be due to the addition of ESP. These results are in agreement with Shrestha and Noomhorm [55].

\subsubsection{Color Measurements of Biscuits}

Color is one of the most important quality attributes of biscuits [55]. Color measurements of biscuits are illustrated in Table 8. Data indicated that supplementation with ESP and pumpkin powder significantly decreased the lightness (L) values of biscuits. Sample No. 1 recorded the highest value (74.06), while sample No. 5 had the lowest (59.25). The redness (a) values increased significantly in sample No. 5 (7.87) compared with No. 1 (2.45). Regarding yellowness (b) values, supplementation with ESP significantly increased the yellowness of biscuits, whereas, sample No. 5 recorded the maximal b value, in contrast, sample No. 1 recorded the minimal b value. Like yellowness value, color saturation value (c) of the same sample No. 5 was found to be the highest value (31.76). In contrast, the same sample had the lowest hue angle (h) value (75.63), compared with control sample (84.86). The resultant in Table 8 showed that the color of samples No. 1 and No. 2 was yellow, while samples No. 3, No. 4 and No. 5 was Orange yellow. These results are in agreement with those reported by Pereira et al. [56].

\subsubsection{Texture Profile Analysis of Biscuits (TPA)}

Texture analysis is primarily concerned with measurement of the mechanical properties of a product, often a

Table 8. Color measurements of biscuits*.

\begin{tabular}{|c|c|c|c|c|c|}
\hline \multirow{2}{*}{ Parameters } & \multicolumn{5}{|c|}{ Biscuit samples } \\
\hline & 1 & 2 & 3 & 4 & 5 \\
\hline $\mathrm{L}$ & $74.06^{\mathrm{a}}$ & $71.66^{\mathrm{b}}$ & $67.43^{\mathrm{c}}$ & $64.74^{d}$ & $59.25^{\mathrm{e}}$ \\
\hline $\mathrm{a}$ & $2.45^{\mathrm{e}}$ & $3.71^{d}$ & $5.17^{\mathrm{c}}$ & $6.84^{\mathrm{b}}$ & $7.87^{\mathrm{a}}$ \\
\hline $\mathrm{b}$ & $26.84^{\mathrm{e}}$ & $27.46^{\mathrm{d}}$ & $28.15^{c}$ & $28.64^{\mathrm{b}}$ & $30.77^{\mathrm{a}}$ \\
\hline C & $26.98^{e}$ & $27.73^{d}$ & $28.56^{\mathrm{c}}$ & $29.45^{b}$ & $31.76^{\mathrm{a}}$ \\
\hline $\mathrm{h}$ & $84.86^{\mathrm{a}}$ & $82.26^{\mathrm{b}}$ & $78.63^{c}$ & $76.53^{d}$ & $75.63^{e}$ \\
\hline Color & Yellow & Yellow & Orange yellow & Orange yellow & Orange yellow \\
\hline
\end{tabular}

${ }^{*} \mathrm{~L}$ (lightness with $\mathrm{L}=100$ for lightness, and $\mathrm{L}=$ zero for darkness), a [(chromaticity on a green $(-)$ to red $(+)$ ], b [(chromaticity on a blue $(-)$ to yellow $(+)$ ], c (color saturation), h [(hue angle where $0^{\circ}=$ red to purple, $90^{\circ}=$ yellow, $180^{\circ}=$ bluish to green and $270^{\circ}=$ blue scale. Values are mean of three replicates $\pm \mathrm{SD}$, number in the same column followed by the same letter are not significantly different at 0.05 level. $1=(0 \mathrm{ESP})$, $2=(5 \%$ ESP $)$, $3=(10 \%$ ESP $), 4=(15 \%$ ESP), $5=(20 \%$ ESP $)$; Data are presented as means $(n=3)$ \& Means within a row with different letters are significantly different at $(\mathrm{P} \leq 0.05)$. 
food product, as they relate to its sensory properties detected by human via applying controlled forces to the product and recording its response in the form of force, deformation and time. Texture measurements can be very valuable for the quality control and process optimization as well as for the development of new products with desirable properties and characteristics [57].

Data in Table 9 presented the textural parameters assessed from texture profile analysis (TPA) test curves results for the biscuits samples. A marked increase in hardness from $2933 \mathrm{~g}$ to $4098 \mathrm{~g}$ was observed. On the other hand, the biscuits become harder with increasing ESP level. Data showed that sample No. 5 had the highest hardness value (4098 g) compared to other samples and control (2933 g). This may be due to the effect of ESP and pumpkin powder in formulation. These results agreed with Kulkarni and Joshi [20] who reported that the replacing $2.5 \%$ of formulation by pumpkin powder, the hardness of the biscuits increased compared control sample. Hoojjat and Zabik [58] and Lee and Beuchat [59] reported that more strength was needed to break cookies incorporated with legumes flour. This might have resulted from incorporation of protein rich flour which need more water to obtain good cookie dough, and the cookies prepared from high-absorption dough tend to be extremely hard.

A similar trend was observed for adhesiveness as it considered maximum negative force generated during probe return. The results in Table 9 showed that biscuit sample No. 5 had the highest value $\left(5.0 \mathrm{~g} \cdot \mathrm{s}^{-1}\right)$ compared with sample No. $1\left(1.0 \mathrm{~g} \cdot \mathrm{s}^{-1}\right)$. In conclusion increment of hardness and adhesiveness may be due to adding ESP and pumpkin powder.

\subsubsection{Sensory Evaluation of Biscuits}

Sensory evaluation is considered to be a valuable tool in solving problems involving food acceptability. It is useful in product improvement, quality maintenance and more important in a new products development [60].

Photographs of biscuits are illustrated in Figure 3. Sensory evaluation of biscuit samples are shown in Table 10. It was observed that there were insignificant differences in appearance, color, odor and taste for all samples. While, there was significant differences between all samples and control for texture parameter. Addition of ESP at $20 \%$ (sample No. 5) significantly decreased the texture compared to the other samples. From the observation data in Table 10 it could be concluded that, the best addition level to obtain high overall acceptability score was $5 \%$ ESP.

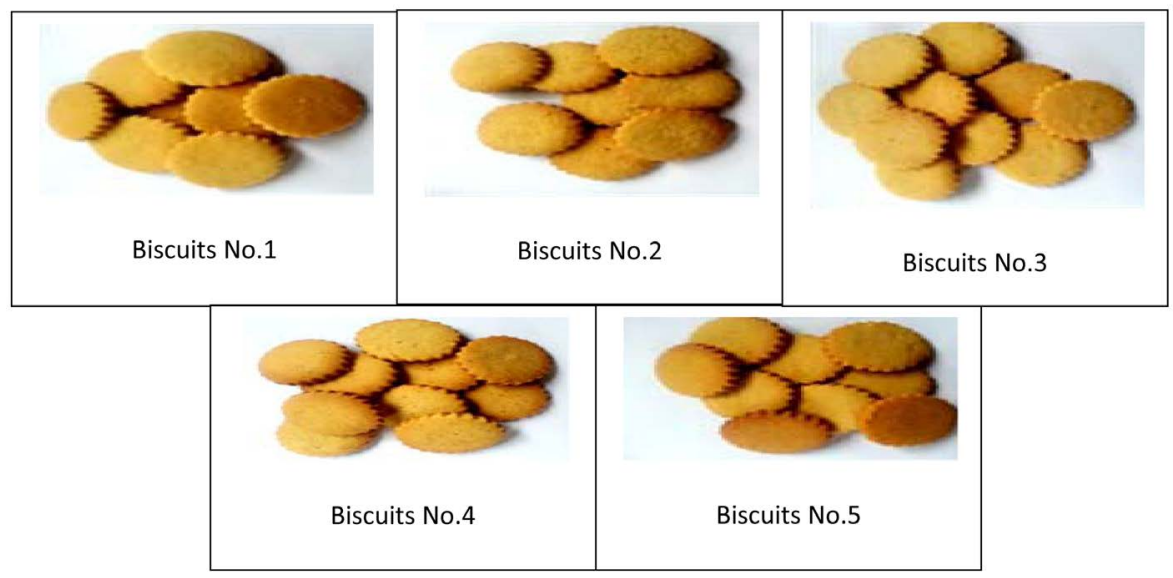

Figure 3. Biscuit photographs [1 = (0 ESP); 2 = (5\% ESP); 3 = (10\% ESP); 4 = (15\% ESP); $5=(20 \%$ ESP $)]$.

Table 9. Texture properties of biscuits.

\begin{tabular}{cccccc}
\hline & \multicolumn{4}{c}{ Biscuit samples } \\
Parameters & 1 & 2 & 3 & 4 \\
Hardness (g) & 2933 & 3234 & 3612 & 3806 \\
Adhesiveness $\left(\mathrm{g} \cdot \mathrm{s}^{-1}\right.$ ) & 1.0 & 2.0 & 2.0 & 3.0 & 5.0 \\
\hline
\end{tabular}

$1=(0.0 \mathrm{ESP}), 2=(5 \% \mathrm{ESP}), 3=(10 \% \mathrm{ESP}), 4=(15 \% \mathrm{ESP}), 5=(20 \% \mathrm{ESP})$. 
Table 10. Sensory evaluation of biscuits.

\begin{tabular}{|c|c|c|c|c|c|}
\hline \multirow{2}{*}{ Parameters } & \multicolumn{5}{|c|}{ Biscuit samples } \\
\hline & 1 & 2 & 3 & 4 & 5 \\
\hline Appearance(10) & $9.45^{\mathrm{a}}$ & $8.91^{\mathrm{b}}$ & $8.42^{\mathrm{b}}$ & $8.85^{\mathrm{ab}}$ & $8.65^{\mathrm{ab}}$ \\
\hline Color (10) & $9.64^{\mathrm{a}}$ & $9.25^{\mathrm{ab}}$ & $8.55^{\mathrm{b}}$ & $8.51^{\mathrm{b}}$ & $8.71^{\mathrm{ab}}$ \\
\hline Odor (10) & $9.53^{\mathrm{a}}$ & $9.11^{\mathrm{a}}$ & $9.12^{\mathrm{a}}$ & $8.95^{\mathrm{a}}$ & $8.82^{\mathrm{a}}$ \\
\hline Texture (10) & $9.51^{\mathrm{a}}$ & $7.92^{\mathrm{b}}$ & $7.65^{\mathrm{b}}$ & $6.75^{\mathrm{c}}$ & $6.61^{\mathrm{c}}$ \\
\hline Taste (10) & $9.35^{\mathrm{a}}$ & $9.13^{\mathrm{ab}}$ & $8.85^{\mathrm{ab}}$ & $8.45^{\mathrm{ab}}$ & $8.35^{\mathrm{b}}$ \\
\hline Overall acceptability (50) & 47.48 & 44.32 & 42.59 & 41.51 & 41.14 \\
\hline
\end{tabular}

$1=(0.0$ ESP $), 2=(5 \%$ ESP $), 3=(10 \%$ ESP $), 4=(15 \%$ ESP $), 5=(20 \%$ ESP $)$. Data are presented as means $(n=10) \&$ means within a row with different letters are significantly different at $(\mathrm{P} \leq 0.05)$.

\section{Conclusion}

Celiac disease is an autoimmune disorder characterized by intolerance to gluten. It is considered to be a potentially significant cause of poor health in population. All ingredients under study influenced the flat bread and biscuits quality. The importance of added extracted soy protein (ESP), pumpkin powder, rice flour and xanthan gum to cassava flour was evident in assessment of the parameters: nutritional value, texture, color and organoleptic acceptability which improved as these ingredients added. The optimized additions of ESP were $2.5 \%$ and $5 \%$ for flat bread and $5 \%$ for biscuits. The optimal ratio of cassava and rice flour was $1: 1(\mathrm{w} / \mathrm{w}), 0.1 \%$ xanthan gum and 7\% pumpkin powder. Addition of xanthan gum helps in formulation of dough. It acts like wheat gluten. On the other hand, pumpkin powder improved the nutritional value of the produced flat bread and biscuits with attractive color to the products. Thus, the produced flat bread and biscuits are suitable for those people suffering from celiac disease especially for children with protein and vitamins deficiency. Addition of ESP not only enhanced the nutritional value of flat bread but also retarded the staling. This study succeeded to achieve flat bread and biscuits nearly with high quality and acceptability.

\section{References}

[1] Demirkesen, I., Sumnu, G. and Sahin, S. (2013) Quality of Gluten-Free Bread Formulations Baked Indifferent Ovens. Food and Bioprocess Technology, 6, 746-753. http://dx.doi.org/10.1007/s11947-011-0712-6

[2] Catassi, C. and Fasano, A. (2008) Celiac Disease. Current Opinion in Gastroenterology, 24, 687-691. http://dx.doi.org/10.1097/MOG.0b013e32830edc1e

[3] Motrena, S.G., Carvalho, M.J., Canada, J., Alvarenga, N.B., Lidon, F.C. and Elisa, B.P. (2011) Characterization of Gluten-Free Bread Prepared from Maize, Rice and Tapioca Flours Using the Hydrocolloid Seaweed Agar-Agar. Recent Research in Science and Technology, 3, 64-68.

[4] Al-Dmoor, H.M. (2012) Flat Bread: Ingredients and Fortification. Quality Assurance and Safety of Crops Foods, 4, 2-8. http://dx.doi.org/10.1111/j.1757-837X.2011.00121.X

[5] Phimolsiripol, Y., Mukprasirt, A. and Schoenlechner, R. (2012) Quality Improvement of Rice Based Gluten Free Bread Using Different Dietary Fiber Fractions of Rice Bran. Journal of Cereal Science, 56, 389-395. http://dx.doi.org/10.1016/j.jcs.2012.06.001

[6] Sanchez, H.D., Osella, C.A. and de la Torre, M.A. (2002) Optimization of Gluten Free Bread Prepared from Corn Starch, Rice Flour and Cassava Starch. Journal of Food Science, 67, 416-419. http://dx.doi.org/10.1111/j.1365-2621.2002.tb11420.x

[7] Sciarini, L.S., Ribotta, P.D., Leon, A.E. and Perez, G.T. (2008) Influence of Gluten-Free Flours and Their Mixtures on Batter Properties and Bread Quality. Food and Bioprocess Technology, 3, 577-585. http://dx.doi.org/10.1007/s11947-008-0098-2

[8] Turabi, E., Sumnu, G. and Sahin, S. (2008) Optimization of Baking of Rice Cakes in Infrared-Microwave Combination Oven by Response Surface Methodology. Food and Bioprocess Technology, 1, 64-73. http://dx.doi.org/10.1007/s11947-007-0003-4 
[9] Ogunjobi, M.A.K. and Ogunwolu, S.O. (2010) Physicochemical and Sensory Properties of Cassava Flour Biscuits Supplemented with Cashew Apple Powder. Journal of Food Technology, 8, 24-29. http://dx.doi.org/10.3923/jftech.2010.24.29

[10] Balagopalan, C. (2002) Cassava Utilization in Food and Feed Industry. In: Hillocks, R.J., Thresh, J.M. and Beelloti, A.C., Eds., Biology, Production and Utilization, CAB International, Cassava, 301-318. http://dx.doi.org/10.1079/9780851995243.0301

[11] Moore, M.M., Heinbockel, M., Dockery, P., Ulmer, H.E. and Arendt, E.K. (2006) Network Formation in Gluten-Free Bread with Application of Transglutaminase. Cereal Chemistry, 83, 28-36. http://dx.doi.org/10.1094/CC-83-0028

[12] Anton, A. and Artfield, S. (2008) Hydrocolloids in Gluten Free Breads: Review. International Journal of Food Science and Nutrition, 59, 11-23. http://dx.doi.org/10.1080/09637480701625630

[13] Bhaskarachary, K., Ananthan, R. and Longvah, T. (2008) Carotene Content of Some Common (Cereals, Pulses, Vegetables, Spices and Condiments) and Unconventional Sources of Plant Origin. Food Chemistry, 106, 85-89. http://dx.doi.org/10.1016/j.foodchem.2007.05.071

[14] Bendich, A. (1989) Carotenoids and the Immune Response. The Journal of Nutrition, 119, 112-115.

[15] Siems, S., Wiswedel, I., Salerno, C., Crifo, C., Augustin, L.S., Langhans, C.D. and Sommerberg, O. (2005) $\beta$-Carotene Breakdown Products May Impair Mitochondrial Functions Potential Side Effects of High Dose $\beta$-Carotene Supplementation. Journal Nutritional Biochemistry, 16, 385-397. http://dx.doi.org/10.1016/j.jnutbio.2005.01.009

[16] Lazaridou, A., Duta, D., Papageorgiou, M., Belc, N. and Biliaderis, C.G. (2007) Effect of Hydrocolloids on Dough Rheology and Bread Quality Parameters in Gluten-Free Formulations. Journal of Food Engineering, 79, 1033-1047. http://dx.doi.org/10.1016/j.jfoodeng.2006.03.032

[17] Willhoft, E.M. (1971) Bread Staling: I.-Experimental Study. Journal of the Science of Food and Agriculture, 22, 176180. http://dx.doi.org/10.1002/jsfa.2740220406

[18] Mehta, K.R., Shivkar, S.M. and Shekhar, A. (2014) A Study of Multigrain Gluten Free Groundnut and Edible Gum Biscuits. International Journal of Food and Nutritional Sciences, 3, 201-206. www.ask.com

[19] Prasad, K., Singh, Y. and Anil, A. (2012) Effects of Grinding Methods on the Characteristics of Pusa 1121 Rice Flour. Journal of Tropical Agriculture and Food Science, 40, 193-201.

[20] Kulkarni, A.S. and Joshi, D.C. (2013) Effect of Replacement of Wheat Flour with Pumpkin Powder on Textural and Sensory Qualities of Biscuit. International Food Research Journal, 20, 587-591.

[21] Oyewole, O.B., Sanni, L.O. and Ogunjobi, M.A. (1996) Production of Biscuits Using Cassava Flour. Nigerian Food Journal, 14, 24-29.

[22] AOAC (2005) Official Methods of Analysis of Association of Official Analytical Chemists. In: Kenesseth Helrick, B., Ed., 15th Edition.

[23] Santra, M., Rao, V.S. and Tamhankar, S.A. (2003) Modification of AACC Procedure for Measuring $\beta$-Carotene in Early Generation Durum Wheat. Cereal Chemistry, 80, 130-131. http://dx.doi.org/10.1094/CCHEM.2003.80.2.130

[24] Food and Nutrition Board, Institute of Medicine (2001) Dietary Reference Intakes: Vitamin A, Vitamin K, Arsenic, Boron, Chromium, Copper, Iodine, Iron, Manganese, Molybdenum, Nickel, Silicon, Vanadium, and Zinc. National Academy Press, Washington DC, 82-161.

[25] Yamazaki, W.T. (1953) An Alkaline Water Retention Capacity Test for the Evaluation of Cookie Baking Potentialities of Soft Winter Wheat Flours. Cereal Chemistry, 30, 242-246.

[26] Kitterman, J.S. and Rubenthaler, G.L. (1971) Assessing the Quality of Early Generation Wheat Selection with the Micro AWRC Test. Cereal Science Today, 16, 313-316.

[27] Beuchat, L.R. (1977) Functional and Electrophoretic Characteristics of Succinylated Peanut Flour Protein. Journal of Agricultural and Food Chemistry, 25, 258-261. http://dx.doi.org/10.1021/jf60210a044

[28] James, C.S. (1995) General Food Studies. In: Analytical Chemistry of Foods, Chapter 6, Blachie Academic \& Professional, 137-171. http://dx.doi.org/10.1007/978-1-4615-2165-5_6

[29] Gains, C.S. (1991) Instrumental Measurement of the Hardness of Cookies and Crackers. Cereal Foods World, 36, 989996.

[30] Sai Manohar, R. and Haaridas, R.P. (1997) Effect of Mixing Period and Additives on the Rheological Characteristics of Dough and Quality of Biscuits. Journal of Cereal Science, 25,197-206. http://dx.doi.org/10.1006/jcrs.1996.0081

[31] AACC (2002) Approved Method of American Association of Cereal Chemists. Approved Methods of AACC Published by the American Association of Cereal Chemists. 13thEdition, St. Paul, Inc., Minnesota.

[32] Mc Gurie, R.G. (1992) Reporting of Objective Color Measurements. HortScience, 27, 1254-1255.

[33] Land, D.G. and Shepherd, R. (1988) Scaling and Ranking Methods. In: Piggott, J.R., Ed., Sensory Analysis of Foods, 
Elsevier Applied Science, London, 155-185.

[34] Larmond, E. (1977) Laboratory Methods for Sensory Evaluation of Foods. Canadian Government Publishing Centre, Otawa.

[35] Tharise, N., Julianti, E. and Nurminah, M. (2014) Evaluation of Physico-Chemical and Functional Properties of Composite Flour from Cassava, Rice, Potato, Soybean and Xanthan Gum as Alternative of Wheat Flour. International Food Research Journal, 21, 1641-1649.

[36] Pongjanta, J., Naulbunrang, A., Kawngdang, S., Manon, T. and Thepjaikat, T. (2006) Utilization of Pumpkin Powder in Bakery Products. Songklanakarin Journal of Science and Technology, 28, 71-79.

[37] Hegazy, A.I., Ammar, M.S. and Ibrahium, M.I. (2009) Production of Egyptian Gluten-Free Bread. World Journal of Dairy \& Food Sciences, 4, 123-128.

[38] Pinheiro-Santana, H.M., Stringheta, P.C., Brandao, S.C.C., Paez, H.H. and de Queiróz, V.M.V. (1998) Evaluation of Total Carotenoids, $\alpha$ - and $\beta$-Carotene in Carrots (Daucus carota L.) during Home Processing. Food Science and Technology (Campinas), 18. http://dx.doi.org/10.1590/S0101-20611998000100009

[39] See, E.F., Wan Nadiah, W.A. and Noor Aziah, A.A. (2007) Physico-Chemical and Sensory Evaluation of Bread Supplemented with Pumpkin Flour. ASEAN Food Journal, 14, 123-130.

[40] FAO/WHO (2004) Vitamin and Mineral Requirements in Human Nutrition. 2nd Edition, World Health Organization and Food and Agriculture Organization of the United Nations.

[41] Olapade, A.A. and Ogunade, O.A. (2014) Production and Evaluation of Flours and Crunchy Snacks from Sweet Potato (Ipomea batatas) and Maize Flours. Instituto Federal do Rio de Janeiro, 21, 203-208.

[42] Hanee, M.A. and Yaseen, G. (2014) Novelty Formulas of Free Gluten Flat Bread for Celiac Disease Patients. World Journal of Medical Sciences, 11, 306-311.

[43] Davidou, S., LeMeste, M., Debever, E. and Bekaert, D. (1996) A Contribution to the Study of Staling of White Bread: Effect of Water and Hydrocolloid. Food Hydrocolloids, 10, 375-383. http://dx.doi.org/10.1016/S0268-005X(96)80016-6

[44] Rojas, J.A., Rosell, C.M. and Benedito, C. (1999) Pasting Properties of Different Wheat Flour-Hydrocolloid System. Food Hydrocolloids, 13, 27-33. http://dx.doi.org/10.1016/S0268-005X(98)00066-6

[45] Brennan, J.S., Higgins, K.F., Cordell, J.R. and Stamatiou, V.A. (2004) Juvenile Salmon Composition, Timing Distribution, and Diet in Marine Nearshore Waters of Central Puget Sound in 2001-2002. King Country Department of Natural Resources and Parks, Seattle, 164 p.

[46] Guarda, A., Rosell, C.M., Benedito, C. and Galotto, M.J. (2004) Different Hydrocolloids as Bread Improves and Antistaling Agents. Food Hydrocolloids, 18, 241-247. http://dx.doi.org/10.1016/S0268-005X(03)00080-8

[47] Duska, C., Dubravka, N., Dubravka, T., Ingrid, B. and Domagoj, G. (2007) Gluten Free Bread Production by the Corn Meal and Soybean Flour Extruded Blend Usage. Agriculture Conspectus Scientifics, 72, 227-232.

[48] Shaikh, I.M., Shalini, K.G. and Ananthanarayan, L. (2007) Staling of Chapatti (Indian Unleavened Flat Bread). Food Chemistry, 101, 113-119. http://dx.doi.org/10.1016/j.foodchem.2006.01.015

[49] Mahmoud, R.M., Yousif, E.I., Gadallah, M.G.E. and Alawneh, A.R. (2013) Formulations and Quality Characterization of Gluten-Free Egyptian Balady Flat Bread. Annals of Agricultural Science, 58, 19-25. http://dx.doi.org/10.1016/j.aoas.2013.01.004

[50] Lorena, S.S., Pablo, D.R., Alberto, E.L. and Gabriela, T.P. (2008) Influence of Gluten-Free Flours and Their Mixtures on Batter Properties and Bread Quality. Food Bioprocess Technol, 3, 577-588.

[51] Kadam, M.L., Salve, R.V., Mehrajfatema, Z.M. and More, S.G. (2012) Development and Evaluation of Composite Flour for Missi Roti/Chapatti. Journal of Food Processing \& Technology, 3.

[52] Kumar, S., Rekha and Sinha, L. (2010) Evaluation of Quality Characteristics of Soy Based Millet Biscuits. Advances in Applied Science Research, 1, 187-196.

[53] Onweluzo, J.C. and Lwezu, E.N. (1998) Composition and Characteristics of Cassava Soy Bean and Wheat Soy Bean Biscuits. Journal of Food Science and Technology, 35, 128-131.

[54] Booth, S.L., Johns, T. and Kuhnlein, H.V. (1992) Natural Food Sources of Vitamin A and Provitamin A. UNU Food and Nutrition Bulletin, 14, 6-19.

[55] Shrestha, A.K. and Noomhorm, A. (2002) Comparison of Physic-Chemical Properties of Biscuits Supplemented with Soy and Kinema Flours. International of Journal Science and Technology, 37, 361-368.

[56] Pereira, D., Paula, M.R.C. and Raquel, P.F. (2013) Analysis of the Physical-Chemical and Sensorial Properties of Maria Type Cookies. Acta Chimica Slovaca, 6, 269-280.

[57] Bourne, M.C. (1978) Texture Profile Analysis. Food Technology, 32, 62-66, 72. 
[58] Hoojjat, P. and Zabik, M.E. (1984) Sugar-Snap Cookies Prepared with Wheat Navy Bean-Sesame Seed Flour Blends. Cereal Chemistry, 61, 41-44.

[59] Lee, C. and Beuchat, L.R. (1991) Functional and Sensory Properties of Muffins and Cookies Containing Dried Fermented Peanut Milk. Lebensmittel-Wissenschaft \& Technologie, 24, 528-534.

[60] Kramer, A. and Twigg, B.A. (1974) Quality Control for the Food Industry. 3rd Edition, AVI. Inc., Westport. 